maintained in the accelerating tube, thus producing a stream of swift protons corresponding to a current of 20 micro-amperes. By the multiple acceleration of charged atoms, Lawrence and Livingston in California have been able to obtain a stream of protons of energy so high as $1,200,000$ volts by the use of a voltage so low as 4,000 volts.

\section{Effects of Atomic Bombardment}

Is the second part of his address, Lord Rutherford described the applications of atomic projectilesAfter considering the way in which swift $\alpha$-particles from radioactive substances have been used for throwing light on the dimensions of the atomic nucleus, he gave an interesting account of experiments on the transmutation of matter. This has been effected by the bombardment of matter by swift atomic projectiles of different kinds. In 1919, Rutherford was able to demonstrate the disintegration of the nitrogen nucleus as a result of a close collision with an $\alpha$-particle in which a swift proton was expelled. The discovery of the 'neutron' followed upon experiments by Bothe, who observed a very penetrating type of radiation when beryllium was bombarded by $\alpha$-particles. Chadwick carried out further experiments by counting methods, and concluded that the radiation consists of a flight of material particles which are supposed to be close combinations of a proton and an electron. Within the last year, Cockeroft and Walton have obtained definite evidence that certain atoms can be transformed by a stream of fast protons produced artificially in a discharge tube. This new method of attack, so successfully begun, is certain to give us much new information on the structure of nuclei and the problem of the transmutation of the elements.

\section{Egypt and the Nile}

THE presidential address delivered by Sir Murdoch Macdonald to the Institution of Civil Engineers at the first meeting of the session on November 1 was almost entirely devoted to a consideration of the engineering development of Egypt and the Sudan, with which his life work has been closely associated, and, in particular, to the measures taken to bring into cultivation vast areas of waste land which have lain unproductive for centuries. Of the 360,000 square miles over which the King of Egypt rules, 95 per cent is desert. The combined area of the two cultivated districts of Lower and Upper Egypt is only about 12,000 square miles, one tenth of the area of Great Britain and Ireland; and the narrow strip of cultivated land, running for some 550 miles on each side of the Nile from Cairo to Assuan, has an average width of not more than 6 miles. Referring to the geological history of the country, Sir Murdoch said that, on the supposition that the Delta of the Nile lay in an ancient bay of the Mediterranean now filled with silt, the original mouth of the river was at Cairo. The depth of silt and sand in that locality indicates that the river once ran at a much lower level than it does now. From records of water levels on the Roda gauge, near Cairo, extending over many hundred years, it has been deduced that the bed of the river and the general level of the cultivable land must have been raised at the rate of $1 \mathrm{~mm}$. a year and the process has been going on probably for 20,000 years.

\section{Irrigation Schemes in Egypt and the Sudan}

AFTER alluding to ancient indigenous methods of providing water for crops, Sir Murdoch Macdonald proceeded to discuss the modern system of perennial irrigation (under which provision has also to be made for drainage) adopted in consequence of the introduction of cotton cultivation by the Khedive, Mohammed Ali. The first work of construction in that connexion was the Delta Barrage, completed in 1861 , but, owing to defects in the foundations, not brought into effective use until the British occupation, when the works were strengthened. The succeeding structures of the same type at Assuan, Asyut, Esna and Nag Hammadi were historically noticed, and then reference was made to various schemes put forward from time to time for impounding the water of the Blue Nile and the White Nile above Khartoum. Figures were quoted to show the benefit to Egypt of the Assuan Dam. The 1,000 million cubic metres of water originally impounded would be increased by the re-heightening to at least 4,800 million cubic metres and the normal summer supply would be increased by about 66 per cent. The contemplated Gebel Aulia reservoir would contain about 3,000 million cubic metres and would possibly be able to pass 2,500 million into the river. A Lake Albert Dam, only 8 metres in height, would impound about 40,000 million cubic metres, but would require to be coupled with works which would conserve the waters as they passed down the river and prevent their being wasted as at present in the Sudd region. Sir Murdoch touched upon the schemes put forward for preventing the immense loss of water due to evaporation from the marsh formed by the main stream between the Sobat and Bahr-el-Ghazal. The whole territory including the marsh region has an area of about 90,000 square miles and might become a wonderful timber growing country. Summing up the position between Egypt and the Anglo-Egyptian Sudan, he said that the large volumes of water passing in flood, of which Egypt can only use a small part, would make it possible for the Sudan to divert a great quantity without detriment to her neighbour. All the conceivable diminution by future reservoirs would not be sufficient to reduce the flood volume below the known requirements of Egypt for the fertilisation of its flood crops.

\section{Telephony and Telegraphy in Great Britain}

Sir Thomas Purves, engineer to the Post Office, contributes to the British Industries Number forming a supplement to the Times of November 1 an interesting article on the industries connected with telegraphy and telephony. In the earlier days of telegraphy, Great Britain was pre-eminent in the manufacture of high quality Morse and Wheatstone automatic apparatus. The very fact of the excellence

No. 3289, VoL. 130] 